\title{
Canadian Beaufort Sea 2000: The Environmental and Social Setting
}

\author{
G. BURTON AYLES ${ }^{1}$ and NORMAN B. SNOW ${ }^{2}$
}

(Received 1 March 2001; accepted in revised form 2 January 2002)

\begin{abstract}
The Beaufort Sea Conference 2000 brought together a diverse group of scientists and residents of the Canadian Beaufort Sea region to review the current state of the region's renewable resources and to discuss the future management of those resources. In this paper, we briefly describe the physical environment, the social context, and the resource management processes of the Canadian Beaufort Sea region. The Canadian Beaufort Sea land area extends from the Alaska-Canada border east to Amundsen Gulf and includes the northwest of Victoria Island and Banks Island. The area is defined by its geology, landforms, sources of freshwater, ice and snow cover, and climate. The social context of the Canadian Beaufort Sea region has been set by prehistoric Inuit and Gwich'in, European influence, more recent land-claim agreements, and current management regimes for the renewable resources of the Beaufort Sea.
\end{abstract}

Key words: Beaufort Sea, Inuvialuit, geography, environment, ethnography, communities

RÉSUMÉ. La Conférence de l'an 2000 sur la mer de Beaufort a attiré un groupe hétérogène de scientifiques et de résidents de la région de la mer de Beaufort en vue d'examiner le statut actuel des ressources renouvelables de cette zone et de discuter de leur gestion future. Dans cet article, on décrit brièvement l'environnement physique, le contexte social et les processus de gestion des ressources de la zone canadienne de la mer de Beaufort. La superficie terrestre de la mer de Beaufort au Canada s'étend de la frontière entre ce pays et l'Alaska jusqu' au golfe Amundsen à l'est, et elle englobe le nord-ouest de l'île Victoria et de l'île Banks. Cette zone est définie par sa géologie, son relief, ses sources d'eau douce, son couvert glaciel et nival ainsi que son climat. Le contexte social de la région de la mer de Beaufort canadienne a été établi par les Inuits et Gwich'in préhistoriques, l'influence européenne, les récentes ententes territoriales ainsi que les régimes actuels de gestion des ressources renouvelables de la mer de Beaufort.

Mots clés: mer de Beaufort, Inuvialuit, géographie, environnement, ethnographie, communautés

Traduit pour la revue Arctic par Nésida Loyer.

\section{INTRODUCTION}

The fish, marine mammals, and sea birds of the Canadian Beaufort Sea region exist under extreme environmental conditions-cold temperatures, large seasonal fluctuations in solar radiation, long periods of snow and ice cover, short growing seasons, and generally impoverished terrestrial and aquatic environments-which affect the productivity, species diversity, behaviour, and other characteristics of the animals and the ecosystems. This paper summarizes the environmental and social setting for the resources and their use. A brief description of the region includes geological history, ecological characteristics, climate and weather, freshwater inputs, and oceanography. It also depicts the social environment, from the history of the indigenous peoples of the region to European contact, the status of communities in the 1990s, and current resource management regimes established under comprehensive land-claim agreements between Canada and the Inuvialuit and Gwich' in. The published information on the Canadian Beaufort Sea region is extensive. This report is intended to provide a context for the resource-specific papers in this volume, not to describe all aspects of the region's environment and its people. For a more complete understanding of the area, readers are directed to the publications referred to in the text.

\section{GEOLOGICAL HISTORY}

The region considered includes the Canadian Beaufort Sea, extending into Amundsen Gulf, and associated coastal areas. The coastal area extends some $750 \mathrm{~km}$ along the mainland from the Alaska-Yukon border at $141^{\circ} \mathrm{W}$, east through the Mackenzie Delta to Clinton Point at $121^{\circ} \mathrm{W}$, the entrance to Dolphin and Union Strait, then north to include the west coast of Victoria Island and the south and west coasts of Banks Island to M'Clure Strait at approximately $75^{\circ} \mathrm{N}$. The marine area covers approximately $394000 \mathrm{~km}^{2}$. The region covered has been extended where appropriate, e.g., to describe ocean currents or movements of marine birds or mammals (Fig. 1).

The Beaufort Sea was not always as it is today. The basin was initiated by events related to the opening of the

${ }^{1}$ Fisheries Joint Management Committee, Box 2120, Inuvik, Northwest Territories X0E 0T0, Canada; aylesb@escape.ca

${ }^{2}$ Joint Secretariat - Inuvialuit Renewable Resources Committees, Box 2120, Inuvik, Northwest Territories X0E 0T0, Canada

(C) The Arctic Institute of North America 


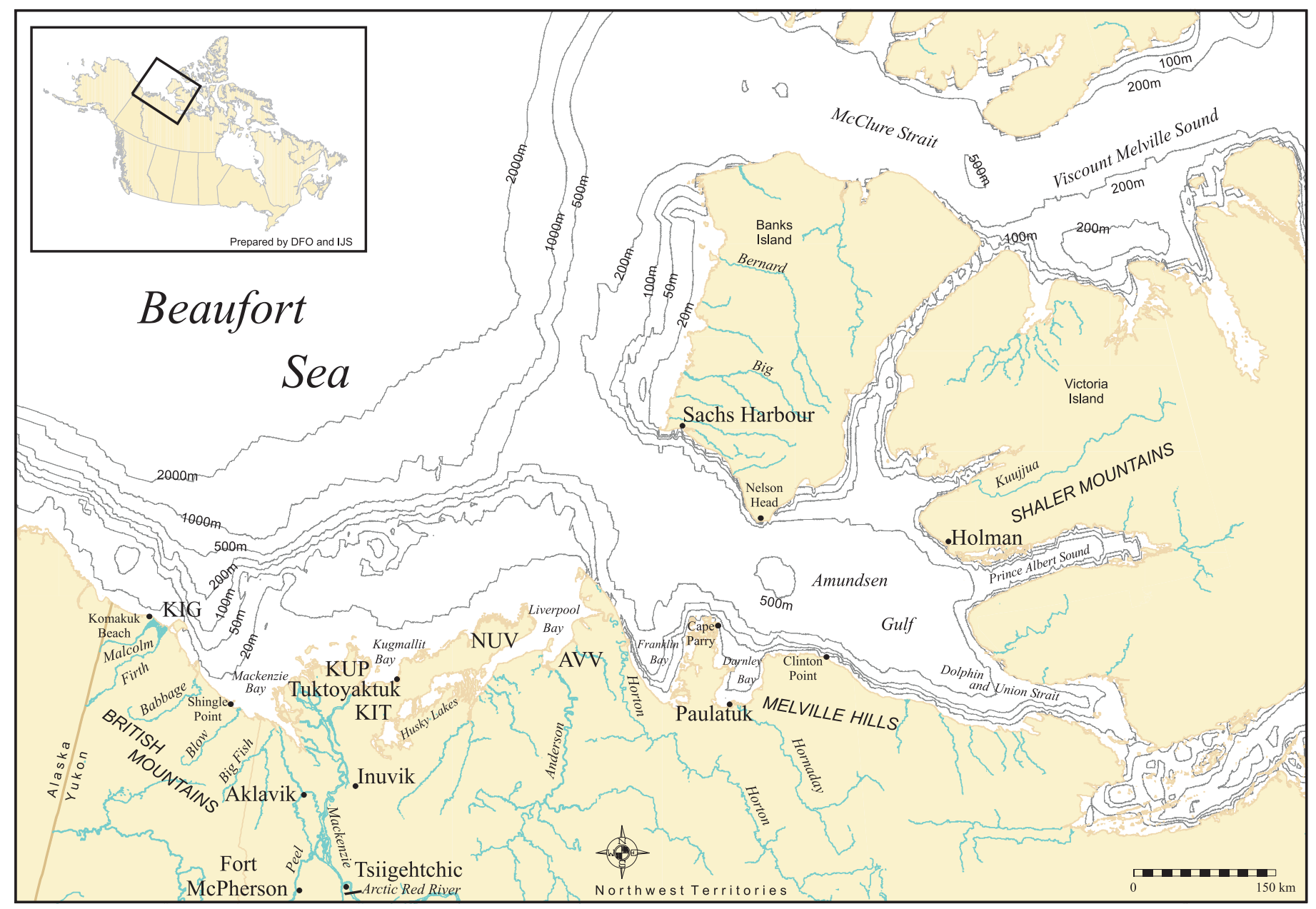

FIG. 1. Canadian Beaufort Sea area, showing ocean depth contours, settlements, major rivers, and geographical features mentioned in text. Abbreviations indicate geographical centres of Inuvialuit groups at time of first European contact: KIG - Kigirktarugmiut; KUP - Kupugmiut; KIT - Kittegaryumiut; NUV - Nuvorugmiut; AVV - Avvagmiut.

Canada Basin between 130 and 80 million years ago. As the base rocks subsided, thick layers of sandstone and mudstone sediments were deposited to a maximum depth of $12 \mathrm{~km}$ in an area north of the present Mackenzie Delta. (See Blasco et al., 1990 for a description of the stratigraphic and structural setting of the Beaufort-Mackenzie basin and Pelletier, 1984, 1987 for detailed maps and descriptions of the sedimentology, geology, and geophysics.) During the Paleocene-Eocene interval (66.4-36.6 million years ago), the Arctic Ocean was a very restricted ocean that was connected to the other ancient oceans by shallow, narrow seaways. There was no connection through what is now the Bering Strait (McNeil, 1990). It was also a relatively warm period, and redwood forests were found on the Arctic islands (McMillan, 1986). Temperatures dropped gradually during the Eocene and then rapidly at the beginning of the Oligocene, approximately 36 million years ago. The modern Arctic Ocean began to be established at this time with the broadening and deepening of connections to the North Atlantic by the gradual spreading of the sea floor. Temperatures warmed slightly during the Oligocene, and by the early to middle Miocene (23.7-14 million years ago), walnuts (Juglans eocineria, an ancestor of the modern butternut) were growing on Banks Island (Hills et al., 1974). This period was a climate maximum (Kennett, 1982), and temperatures in the Beaufort Sea have not returned to that level since. The climate cooled again during the late Miocene, and a marked drop in relative sea level followed, probably as a result of glaciation in the Antarctic beginning about 6 million years ago (McNeil, 1990). The changes in sea level brought significant periods of erosion and deltaic deposition of the sediment layers now hidden beneath the ocean floor. Further climate cooling coincided with the onset of continental glaciation in North America 2.4 to 1.8 million years ago (Blasco et al., 1990; McNeil, 1990).

Four major stages of glaciation have occurred in North America since that time. The most recent, Wisconsin, began about 85000 years ago (Trenhaile, 1990). In the Canadian Beaufort Sea area, ice probably reached its maximum in the Late Wisconsin (23000-18000 years ago), and at that time the ice shelf extended into the offshore (Dyke and Prest, 1987a). Even at its maximum, however, parts of the Canadian Beaufort Sea area remained 
free of ice and certain areas escaped Quaternary glaciation entirely (Welch, 1993a; Vincent, 1989). Banks Island was largely free of ice during the Late Wisconsin, and part of the northwest coast may have escaped glaciation throughout the Quaternary (Vincent, 1989), as may the tops of the Melville Hills on the mainland (Zoltai et al., 1992). By 18000 years ago, the Tukoyaktuk Peninsula to McKinley Bay, part of Anderson Plain, and the Melville Hills were free of ice, as was all but the east coast of Banks Island and most of the Yukon Coastal Plain. The shoreline off the Yukon coast and Mackenzie Delta was much lower, as much as $100 \mathrm{~m}$, and much of the continental shelf was dry land because so much of the global ocean water was sequestered in continental glaciers. By 12000 years ago, the entire area (except parts of Victoria Island) was free of the ice sheet, and the Mackenzie River had started to flow again, as had all the other rivers in the area. The relative sea level off the Mackenzie was still -70 m, but farther east on Victoria Island, the weight of the ice sheet had depressed the land surface to such an extent that relative sea level was up to $115 \mathrm{~m}$ higher than at present. At that time, the ice still covered the majority of central Canada, including much of the Laurentian Great Lakes (Dyke and Prest, 1987a, b).

Permafrost continues to underlie most of the area, and large bodies of massive ground ice are widespread, particularly south of the Beaufort Sea, on eastern Banks Island, and on Prince Albert Peninsula of Victoria Island (Vincent, 1989). The permafrost is generally less than $150 \mathrm{~m}$ thick south of the Delta, but it can be up to $700 \mathrm{~m}$ thick on northern Richards Island and the Tuktoyaktuk Peninsula (Judge et. al., 1987), and up to $1000 \mathrm{~m}$ thick on parts of Banks Island (Vincent, 1989).

\section{ECOREGIONS OF THE CANADIAN BEAUFORT SEA}

The lands bordering the Canadian Beaufort Sea fall into three ecozones, the Northern Arctic, Southern Arctic, and Taiga Plains. The ecozones are the broad subcontinental-scale areas formed by the interaction of macroscale climate, human activity, vegetation, soils, and geological and physiographic features of the country (Marshall and Schut, 1999; Environment Canada, 2001). Counterclockwise from the Alaska-Yukon border, the subdivisions of the ecozones (called ecoregions) adjacent to the Canadian Beaufort Sea are (1) the Yukon Coastal Plain; (2) the Mackenzie Delta; (3) the Tuktoyaktuk Coastal Plain and (4) the Anderson River Plain, on the mainland; (5) the Amundsen Gulf Lowlands, on the mainland and southern Victoria Island; (6) the Banks Island Lowland, also on the shores of Amundsen Gulf; and (7) the Banks Island Coastal Plain, on the west coast of Banks Island (Environment Canada, 2001).

The Yukon Coastal Plain ecoregion is bounded by the Canadian Beaufort Sea on the north and the northern extremities of the Cordilleran Mountain region to the south. It extends approximately $180 \mathrm{~km}$ eastward from the
Alaska-Yukon border to the Mackenzie Delta and varies in width from approximately $5 \mathrm{~km}$ near the Alaskan border to $30 \mathrm{~km}$ at the Babbage River. The topography of the region ranges from 1500 to $2000 \mathrm{~m}$ above sea level in the mountains, to gently sloping erosion surfaces and near-coastal sediment surfaces. The British Mountains to the south have been land since the early Cenozoic Era 40 million years ago (Welch, 1993b), and the Firth River has probably been flowing consistently since that time. The coastline is characterized by spits and lagoons, sand and shingle beaches, and areas of steep cliffs containing exposed ground-ice. The cliffs are continually eroding and slumping under the combined action of waves and permafrost melt (Percy et al., 1985). The ecoregion supports nearly continuous cover of shrubby tundra vegetation: dwarf birch, willow, northern Labrador tea, Dryas spp., and tussock-forming sedge in Arctic coastal habitats, transitioning quickly to alpine tundra in the mountains (Karasiuk, 1993).

The Mackenzie Delta is the largest northern delta in North America and among Arctic deltas, it is second only to the Lena in size (Mackenzie River Basin Committee, 1981; Brunskill, 1986). The delta is formed largely from sediments transported by the Mackenzie River over the last 13000 years. It is flat and dotted with numerous ponds, lakes, and river channels and land varying from stable forested areas to low-relief, polygonal tundra and shallow depositional areas at the mouths of the estuary. Elevations range from sea level to $10-15 \mathrm{~m}$ in the area of Tsiigehtchic (formerly Arctic Red River) and Fort McPherson. The area is generally underlain with permafrost except under many of the large lakes and river channels. The delta extends into the Beaufort Sea, and the nearshore waters are shallow ( $<6 \mathrm{~m}$, up to $25 \mathrm{~km}$ offshore). The Mackenzie Delta ecoregion supports stunted stands of black spruce and tamarack, with secondary quantities of white spruce, and a ground cover of dwarf birch, willow, cottongrass, lichen, and moss. Wetlands extend over 50\% of the ecoregion and are characteristically polygonal peat bogs and fens (Environment Canada, 2001)

The Tuktoyaktuk Coastal Plain ecoregion covers the outer Mackenzie River Delta and the Tuktoyaktuk Peninsula. East of the delta along the Tuktoyaktuk Peninsula, the coast is a succession of spits, sandbars, and giant frost heaves known as pingos. There are some 1400 pingos in the area, including submarine examples (Mackenzie River Basin Committee, 1981). Small lakes cover much of the ecoregion. The vegetation is shrubby tundra of dwarf willow, birch, northern Labrador tea, Dryas spp., and sedge tussocks (Environment Canada, 2001).

The Anderson Plain ecoregion is separated from the Mackenzie Delta and the Tuktoyaktuk Peninsula by a northeast-trending chain of lakes, of which the Eskimo Lakes are the most important. From these lakes the ecoregion extends some $500 \mathrm{~km}$ east to the Melville Hills and Clinton Point on the eastern boundary of Tuktut Nogait National Park at $121^{\circ} \mathrm{W}$. The coastline generally 
consists of low sandy and gravelly beaches with hills behind. An exception is the high cliffs at Cape Parry, which support one of the few breeding colonies of seabirds in the Canadian Beaufort Sea area (Dickson and Gilchrist, 2002), including the only murre colony in the Western Canadian Arctic. The shrubby tundra vegetation consists of dwarf birch, willow, northern Labrador tea, Dryas spp., and sedge tussocks (Environment Canada, 2001).

The Amundsen Gulf Lowlands ecoregion occurs predominantly on southwestern Victoria Island and partially on the mainland. The landscapes are flat and featureless except where broken by the Shaler Mountains on Victoria Island. The dwarf tundra vegetation consists of dwarf willow, birch, and northern Labrador tea, Dryas spp., and Vaccinium spp. Tall dwarf birch, alder, and willow occur on warmer sites (Environment Canada, 2001).

The Banks Island Lowland ecoregion extends to the Amundsen Gulf on the south coast of Banks Island. This ecoregion, classified as having a mid-Arctic ecoclimate, has a vegetative cover of moss and mixed low-growing herbs. The land slopes gently to the south, and marshes and sand beaches are common along the coast (Environment Canada, 2001).

The Banks Island Coastal Plain ecoregion extends along the edge of the Beaufort Sea on the west side of Banks Island. The coastal plain was unglaciated during the last glaciation, and fossil-bearing alluvial sands and gravels of the Miocene to Pliocene age Beaufort Formation extend along the low-lying shoreline (Fyles, 1990). At Nelson Head, cliffs that reach as high as 300 m extend along the coast, but they are not used as nesting sites (Dickson and Gilchrist, 2002). Temperatures are moderated by open water during the late summer and early fall, and the ecoregion is classified as having a low Arctic ecoclimate. Vegetation consists of moss and mixed low-growing herbs and shrubs (Environment Canada, 2001).

Offshore in the study area are three major zones: the continental shelf, the continental slope, and the Canada Basin, which reaches depths of more than $3500 \mathrm{~m}$. From the border and extending east approximately $500 \mathrm{~km}$, the continental shelf is a shallow, flat plain underlain by late Mesozoic to Cenozoic sedimentary rock and covered by a complex series of more recent Neogene and Quaternary marine and deltaic deposits that are up to several hundred metres in depth (see Blasco et al., 1990 for a full description of the stratigraphy). The shelf extends approximately $60 \mathrm{~km}$ offshore in the west, and up to $150 \mathrm{~km}$ offshore at the entrance to Amundsen Gulf. Between $60 \mathrm{~m}$ and $100 \mathrm{~m}$ there is a sharp break, and the shelf slopes sharply away to over $1000 \mathrm{~m}$ depth in less than $50 \mathrm{~km}$ horizontal extent. The shelf is transected by the Mackenzie Trough, a depression approximately $80 \mathrm{~km}$ wide and $150 \mathrm{~km}$ long trending northwest from Mackenzie Bay on the east side of the Mackenzie Delta. This trough was cut more than $400 \mathrm{~m}$ into the continental shelf by repeated action of ice tongues 80000 to 120000 years ago during the Wisconsin glaciation and has been partially infilled by up to $300 \mathrm{~m}$ of sediments (Blasco et al., 1990). At $130^{\circ} \mathrm{W}$, the shelf trends directly north, 100-120 km off Banks Island, then northeast off the Canadian Arctic Archipelago. The shelf-slope break is deeper off Banks Island than it is off the mainland, approximately 250-300 $\mathrm{m}$ depth (Pelletier, 1999). The shelf is intersected by an undersea valley that extends from the entrance of Dolphin and Union Strait, at a depth of over $400 \mathrm{~m}$, through Amundsen Gulf to the shelf-slope break (Pelletier, 1999).

\section{CLIMATE OF THE CANADIAN BEAUFORT SEA REGION}

Climate is one of the most significant factors to which Beaufort Sea birds, mammals, and fish have had to adapt. The climate of the region is well described as "harsh" or "severe"; its climate severity index is 80 in the southern reaches and 80-90 farther north (Phillips, 1990). This compares with indices of over 90 in the eastern and northern Arctic islands, 40-50 for the northern prairies, and 20 for the south coast of British Columbia. Summers are short and cold: mean temperatures are above freezing only during June-September (June-August for Sachs Harbour), and winters are cold and dry (Table 1). July mean air temperatures range from 6.2 to $13.8^{\circ} \mathrm{C}$, and January means range from -24.0 to $-29.9^{\circ} \mathrm{C}$. Precipitation is less than $250 \mathrm{~mm}$ annually throughout the region (Table 1), except in the Mackenzie and British Mountains, where precipitation is estimated to range from $380 \mathrm{~mm}$ in the north to more than $760 \mathrm{~mm}$ in the south (Burns, 1974). The low levels in most of the region compare with levels of $400-500 \mathrm{~mm}$ in the northern prairies and as much as $3200 \mathrm{~mm}$ on parts of the Pacific coast (Phillips, 1990). The climate is mildest and wettest in the Mackenzie Delta at Inuvik, with temperatures and precipitation generally decreasing on the mainland coast and decreasing farther offshore and on the Arctic islands (Table 1). Winter temperatures are somewhat warmer on the Yukon coastal plain than in the Delta. About half of the annual precipitation falls as snow. The lowest ratio of snow to rain is on the Yukon coast, and the highest is at Sachs Harbour (Table 1).

The region encompasses Region III of the seven climatic regions of the Canadian Arctic Islands as described by Maxwell (1981). The distinguishing feature of Region III is the alteration of cyclonic and anticyclonic activity of air masses not found in other Arctic Islands regions. The weather is highly variable, and maritime air masses moving from the west into the Mackenzie Valley and southern Beaufort Sea are major influences. Burns (1973) has described the changes in the dominant air masses. During the winter, cold "continental Arctic" air dominates the huge snow- and ice-covered region, with infrequent penetration of warmer and more moisture-laden "cold maritime Arctic" and "maritime Arctic" air masses. In the spring, additional solar energy input brings rapid changes. The continental Arctic air mass retreats as frontal lows of 
TABLE 1. Beaufort Sea climate normals 1961-90 (Atmospheric Environment Service, 1990).

\begin{tabular}{|c|c|c|c|c|c|c|c|}
\hline $\begin{array}{l}\text { Temperature }\left({ }^{\circ} \mathrm{C}\right) \text {, } \\
\text { Precipitation, and Wind }\end{array}$ & $\begin{array}{c}\text { Komakuk Beach } \\
69^{\circ} 35^{\prime} \mathrm{N} \\
140^{\circ} 11^{\prime} \mathrm{W}\end{array}$ & $\begin{array}{c}\text { Shingle Point } \\
68^{\circ} 57^{\prime} \mathrm{N} \\
137^{\circ} 13^{\prime} \mathrm{W}\end{array}$ & $\begin{array}{c}\text { Inuvik } \\
68^{\circ} 18^{\prime} \mathrm{N}, \\
133^{\circ} 29^{\prime} \mathrm{W}\end{array}$ & $\begin{array}{c}\text { Tuktoyaktuk } \\
69^{\circ} 27^{\prime} \mathrm{N} \\
133^{\circ} 00^{\prime} \mathrm{W}\end{array}$ & $\begin{array}{l}\text { Cape Parry } \\
70^{\circ} 10^{\prime} \mathrm{N}, \\
124^{\circ} 41^{\prime} \mathrm{W}\end{array}$ & $\begin{array}{c}\text { Clinton Point } \\
69^{\circ} 35^{\prime} \mathrm{N} \\
120^{\circ} 48^{\prime} \mathrm{W}\end{array}$ & $\begin{array}{c}\text { Sachs Harbour } \\
72^{\circ} 00^{\prime} \mathrm{N}, \\
125^{\circ} 16^{\prime} \mathrm{W}\end{array}$ \\
\hline \multicolumn{8}{|l|}{ January Temperature $\left({ }^{\circ} \mathrm{C}\right)$} \\
\hline Daily Max & -19.7 & -20.1 & -24.1 & -23.9 & -25.1 & -24.0 & -26.5 \\
\hline Daily Min & -29.5 & -29.6 & -33.5 & -31.2 & -31.6 & -31.1 & -33.5 \\
\hline Daily Mean $\left({ }^{\circ} \mathrm{C}\right)$ & -24.0 & -24.1 & -28.8 & -27.2 & -28.2 & -27.6 & -29.9 \\
\hline \multicolumn{8}{|l|}{ July Temperature $\left({ }^{\circ} \mathrm{C}\right)$} \\
\hline Daily Max. & 12.0 & 15.8 & 19.5 & 15.4 & 9.3 & 11.3 & 9.6 \\
\hline Daily Min & 3.2 & 6.2 & 8.0 & 6.4 & 2.9 & 3.5 & 2.8 \\
\hline Daily Mean & 7.6 & 11.0 & 13.8 & 10.9 & 6.1 & 7.4 & 6.2 \\
\hline Annual Mean Temperature $\left({ }^{\circ} \mathrm{C}\right)$ & -11.0 & NA & -9.5 & -10.5 & -12.0 & -11.4 & -13.7 \\
\hline Rainfall (mm) & 85.0 & 125.2 & 116.0 & 75.4 & 69.8 & 96.6 & 49.7 \\
\hline Snowfall $(\mathrm{cm})$ & 68.9 & 105.8 & 175.2 & 66.8 & 129.6 & 85.0 & 83.8 \\
\hline Total Precipitation (mm) & 154.0 & 231.0 & 257.4 & 142.1 & 160.3 & 181.5 & 126.5 \\
\hline Wind Speed $(\mathrm{km} / \mathrm{h})$ & & & 10 & & 19 & & \\
\hline Most Frequent Direction & & & East & & East & & \\
\hline
\end{tabular}

warmer and moister air begin to penetrate more frequently. By summer, the cold maritime Arctic air mass shrinks to the area of the permanent ice pack, and maritime Arctic air masses form over the open water and along the coasts. Low cloudiness is frequent over the maritime areas. Occasionally, "maritime Tropical" air penetrates the Mackenzie Delta from the south. During the periods with warmer air masses, maximum temperatures can reach the high $20 \mathrm{~s}^{\circ} \mathrm{C}$ (Atmospheric Environment Service, 1990). In the fall, the spring pattern is reversed: temperatures drop rapidly, and cold maritime Arctic air replaces maritime Arctic air masses. Since the air cools faster than the water in the lakes and rivers, moisture is added to the air, causing extensive clouds and snow flurries. As darkness increases, continental Arctic air increases its southward intrusion.

Wind is a significant factor on the coast and offshore. Fishing and hunting areas and settlements are often in protected locations or in places where local landscapes can significantly affect wind movements. As a consequence, local conditions are not necessarily representative of the entire region. The dominant wind direction varies seasonally and ranges from northeast to southeast for both the offshore and coastal Beaufort (Berry et al., 1975; Atmospheric Environment Service, 1990). During the summer, easterly winds are dominant and southerly winds are rare. From July to September, westerly to northwesterly winds in excess of $35 \mathrm{~km} / \mathrm{hr}$ become more frequent. The strong winds from the west and northwest are often responsible for intrusions of multiyear pack ice into coastal waters.

Global climate change, or climate warming, could have a significant effect on the Canadian Beaufort Sea region because high-latitude regions are expected to experience the greatest temperature increases. Projections from General Circulation Models indicate that if concentrations of greenhouse gases were to double, northwestern Canada would warm by $4-5^{\circ} \mathrm{C}$ by the middle of the 21 st century (Cohen, 1997). During 1997 and 1998, the two warmest years on record globally, the global mean temperature was $0.66^{\circ} \mathrm{C}$ above the long-term mean (National Climate Data Center, 1998). However, increases in the Canadian Beaufort Sea area were much greater. In 1998, the warmest year of 1948-98 in both Canadian Climate Regions of the area, mean annual temperatures exceeded the average by $3.8^{\circ} \mathrm{C}$ (Mackenzie District region) and $3.1^{\circ} \mathrm{C}$ (Arctic Tundra region). Four of the ten warmest years on record in the Mackenzie District region have occurred during the decade 1988-98 (Environment Canada, 1998). Climate warming on the Beaufort Sea coast would result in rising sea level, increased storm frequency, and permafrost thawing. The effects would be particularly significant in the Mackenzie Delta area, which has low unprotected coasts and extensive permafrost and ground ice (Shaw et al., 1998).

\section{FRESH AND MARINE WATERS OF THE CANADIAN BEAUFORT SEA REGION}

Extensive studies of the freshwaters of the Yukon North Slope and the Mackenzie Delta took place in the 1970s as a result of proposed hydrocarbon development (see Dome Petroleum Ltd, Esso Resources Canada Ltd, and Gulf Canada Resources Inc., 1982 and Karasiuk et al., 1993 for general reviews); however, few such studies have been published for areas east of the Mackenzie or for the Arctic Islands. There are numerous hydrometric stations on the Mackenzie River, on small streams in the Delta, and around Tuktoyaktuk, as well as several stations west of the Mackenzie (Atmospheric Environment Service, 2001). However, the only long-term records on the interior coastal plains are on the Anderson River, and the only records for the Arctic Islands are for the Big River on Banks Island (discontinued in 1988). Table 2 lists the larger rivers and streams flowing into the Canadian Beaufort Sea, together with their drainage areas and mean annual flows. Two data sets were used to delineate approximate watershed boundaries of watersheds not in the database (Atmospheric 
TABLE 2. Drainage area, mean flow, and flow per unit area for major rivers and streams flowing into the Beaufort Sea. Latitude and longitude are at the water survey gauge for references to gauged rivers (Atmospheric Environment Service, 2001) and at the river mouth for the others.

\begin{tabular}{|c|c|c|c|c|c|c|}
\hline Name & Latitude/Longitude & $\begin{array}{c}\text { Drainage } \\
\text { Area }\left(\mathrm{km}^{2}\right)\end{array}$ & $\begin{array}{l}\text { Mean Flow } \\
\left(\mathrm{m}^{3} / \mathrm{s}\right)\end{array}$ & $\begin{array}{c}\text { Flow/area } \\
\left(1 / \mathrm{s} / \mathrm{km}^{2}\right)\end{array}$ & Years & Reference \\
\hline \multicolumn{7}{|l|}{ Yukon North Slope Streams } \\
\hline Malcolm River & $69^{\circ} 33^{\prime} \mathrm{N}, 139^{\circ} 37^{\prime} \mathrm{W}$ & 1100 & & & & McDonald and Lewis, 1973 \\
\hline Firth River & $69^{\circ} 33^{\prime} \mathrm{N}, 139^{\circ} 29^{\prime} \mathrm{W}$ & 6200 & & & & McDonald and Lewis, 1973 \\
\hline Firth River & $69^{\circ} 18^{\prime} 45^{\prime \prime} \mathrm{N}, 139^{\circ} 34^{\prime} 01^{\prime \prime} \mathrm{W}$ & 5710 & 37.7 & 6.49 & $1975-94$ & Atmospheric Environment Service, 2001 \\
\hline Babbage River & $69^{\circ} 14^{\prime} \mathrm{N}, 138^{\circ} 37^{\prime} \mathrm{W}$ & 5000 & & & & McDonald and Lewis, 1973 \\
\hline Babbage River & $68^{\circ} 50^{\prime} 12^{\prime \prime} \mathrm{N}, 138^{\circ} 40^{\prime} 06^{\prime \prime} \mathrm{W}$ & 1510 & 11.0 & 7.28 & $1972-94$ & Atmospheric Environment Service, 2001 \\
\hline Blow River & $68^{\circ} 57^{\prime} \mathrm{N}, 137^{\circ} 40^{\prime} \mathrm{W}$ & 3700 & & & & McDonald and Lewis, 1973 \\
\hline Big Fish River & $68^{\circ} 38^{\prime} \mathrm{N}, 136^{\circ} 07^{\prime} \mathrm{W}$ & 2300 & & & & McDonald and Lewis, 1973 \\
\hline Arctic Red River & $66^{\circ} 47^{\prime} 24^{\prime \prime} \mathrm{N}, 133^{\circ} 38^{\prime} 38^{\prime \prime} \mathrm{W}$ & 18600 & 160 & 8.60 & $1968-96$ & Atmospheric Environment Service, 2001 \\
\hline Peel River & $67^{\circ} 14^{\prime} 56^{\prime \prime} \mathrm{N}, 134^{\circ} 52^{\prime} 59^{\prime \prime} \mathrm{W}$ & 70600 & 689 & 9.76 & $1969-96$ & Atmospheric Environment Service, 2001 \\
\hline Rat River & $67^{\circ} 40^{\prime} 37^{\prime \prime} \mathrm{N}, 135^{\circ} 43^{\prime} 50^{\prime \prime} \mathrm{W}$ & 1260 & 8.3 & 6.59 & $1981-90$ & Atmospheric Environment Service, 2001 \\
\hline \multicolumn{7}{|c|}{ Mackenzie River (above Arctic Red) } \\
\hline & $67^{\circ} 27^{\prime} 30^{\prime \prime} \mathrm{N}, 133^{\circ} 44^{\prime} 41^{\prime \prime} \mathrm{W}$ & 1680000 & 8980 & 5.34 & $1972-96$ & Atmospheric Environment Service, 2001 \\
\hline \multicolumn{7}{|c|}{ Anderson/Horton Plain Streams } \\
\hline Anderson River & $68^{\circ} 37^{\prime} 51^{\prime \prime} \mathrm{N}, 128^{\circ} 24^{\prime} 48^{\prime \prime} \mathrm{W}$ & 56200 & 142 & 2.53 & $1969-96$ & Atmospheric Environment Service, 2001 \\
\hline Anderson River & $69^{\circ} 67^{\prime} \mathrm{N}, 128^{\circ} 40^{\prime} \mathrm{W}$ & 61118 & & & & M. Wojnarowska, pers. comm. 2000. \\
\hline Horton River & $69^{\circ} 57^{\prime} \mathrm{N}, 126^{\circ} 47^{\prime} \mathrm{W}$ & 27500 & & & & M. Wojnarowska, pers. comm. 2000. \\
\hline Hornaday River & & 14900 & 52.2 & & & Downie, 1995 \\
\hline Hornaday River & $69^{\circ} 22^{\prime} \mathrm{N}, 123^{\circ} 47^{\prime} \mathrm{W}$ & 13120 & & & & M. Wojnarowska, pers. comm. 2000. \\
\hline \multicolumn{7}{|l|}{ Arctic Island Streams } \\
\hline Big River (Banks Is) & $72^{\circ} 28^{\prime} 54^{\prime \prime} \mathrm{N}, 123^{\circ} 24^{\prime} 02^{\prime \prime} \mathrm{W}$ & 3640 & 7.0 & 1.92 & $1975-88$ & Atmospheric Environment Service, 2001 \\
\hline Big River & $72^{\circ} 31^{\prime} \mathrm{N}, 123^{\circ} 12^{\prime} \mathrm{W}$ & 7135 & & & & M. Wojnarowska, pers. comm. 2000 \\
\hline Bernard River (Banks Is) & $73^{\circ} 31^{\prime} \mathrm{N}, 124^{\circ} 20^{\prime} \mathrm{W}$ & 8907 & & & & M. Wojnarowska, pers. comm. 2000 \\
\hline Kuujjua River (Victoria Is) & $71^{\circ} 16^{\prime} \mathrm{N}, 116^{\circ} 50^{\prime} \mathrm{W}$ & 17623 & & & & M. Wojnarowska, pers. comm. 2000 \\
\hline
\end{tabular}

Environment Service, 2001). Northwest Territories and Yukon outlines were from the ArcWorld data set for Canada, while drainage systems were from the National Atlas of Canada (the scale of the data is 1:2000000) (M. Wojnarowska, pers.comm. 2000). The watersheds were created in ArcView 3.2 GIS and a polygon approximately representing a watershed was digitized around the selected river system. The area of the watershed polygons was calculated using a script available in ArcView that calculates the area from a geometry in the View. Calculations were done using a map projected to Lambert Equal Area Projection, with the reference latitude $72.50 \mathrm{~N}$ and $68.00 \mathrm{~N}$ respectively. The hydrometric stations on several of the rivers were located at some distance from the river mouths, and drainage areas and flows are for areas above the stations. Total drainage areas were also calculated for those rivers, using the same methods.

Freshwater inflow to the Canadian Beaufort Sea is dominated by the Mackenzie River. At $333 \mathrm{~km}^{3}$ annually, the Mackenzie has the largest freshwater flow into the North American Arctic and the fourth largest in the entire Arctic, after the Yenisey $\left(630 \mathrm{~km}^{3}\right)$, the Lena $\left(525 \mathrm{~km}^{3}\right)$, and the $\mathrm{Ob}\left(404 \mathrm{~km}^{3}\right)$ (AMAP, 1998). The Mackenzie shelf is the most estuarine of all Arctic shelves (Macdonald et al., 1987). The Mackenzie system is the twelfth largest river system in the world by drainage area and eleventh in mean annual discharge, and it drains one-sixth of Canada (Mackenzie River Basin Committee, 1981). The Mackenzie basin has been the subject of intensive, multi-agency studies under the auspices of the Mackenzie River Basin Committee (1981). The river and its delta are important rearing, overwintering, and migration areas that support over 34 species of fish (Percy, 1975; Percy et al., 1985).

Four major streams flow directly from the mountains to the Yukon Coastal Plain ecoregion and into the Canadian Beaufort Sea: the Malcolm, Firth, Babbage, and Blow Rivers (Fig. 1, Table 2). These rivers have two major sources of water, springs and surface runoff, and as there are no large lakes on any of the systems, flow is highly variable (Leith, 1993). The springs and associated pools are critical for overwintering and spawning of Dolly Varden charr (Salvelinus malma). Other drainage systems (the Rat, Peel, and Arctic Red Rivers) originate in, or are at least partially fed by mountain waters, but enter the Beaufort Sea indirectly, through the Mackenzie.

From west to east, the main drainage systems flowing from the Anderson Plain ecoregion directly into the Beaufort Sea and Amundsen Gulf are the Anderson, Horton, and Hornaday Rivers. All three have large drainage basins compared to the streams to the west of the Mackenzie River, and there are generally small lakes in their headwaters. The gradients of the rivers are less than those flowing across the North Slope, but the gradient of the Hornaday is steep compared to those of the Horton and Anderson (Downie, 1995).

The main systems draining into the Canadian Beaufort Sea from the Arctic Archipelago are the Kuujjua on Victoria Island, which flows out of the Shaler Mountains 
TABLE 3. Monthly stream flows $\left(\mathrm{m}^{3} / \mathrm{s}\right)$ for major rivers and streams flowing into the Canadian Beaufort Sea (Atmospheric Environment Service, 2001).

\begin{tabular}{|c|c|c|c|c|c|c|c|c|c|c|c|c|c|}
\hline River & Jan & Feb & Mar & Apr & May & Jun & Jul & Aug & Sep & Oct & Nov & Dec & Annual \\
\hline Firth & 0 & 0 & 0 & 0.308 & 100 & 136 & 84.6 & 72.2 & 43.7 & 12.4 & 3.51 & 0.45 & 37.7 \\
\hline Babbage & 0 & 0 & 0 & 0.009 & 16 & 61.5 & 16.7 & 18.7 & 15.7 & 3.36 & 0.568 & 0.036 & 11 \\
\hline Mackenzie & 3820 & 3570 & 3330 & 3380 & 13400 & 20600 & 17300 & 13700 & 11300 & 8960 & 4650 & 3670 & 8980 \\
\hline Arctic Red & 15 & 13.2 & 12.3 & 13.9 & 363 & 518 & 309 & 340 & 208 & 77 & 26.1 & 18.3 & 160 \\
\hline Peel & 89.1 & 79.4 & 73.9 & 78.1 & 1770 & 2420 & 1190 & 1070 & 869 & 367 & 154 & 107 & 689 \\
\hline Rat & 0.028 & 0.001 & 0 & 0.001 & 13.3 & 33 & 22.2 & 16.9 & 10.7 & 2.64 & 0.869 & 0.183 & 8.31 \\
\hline Anderson & 21.4 & 15.9 & 12.6 & 11.8 & 368 & 611 & 233 & 129 & 135 & 90.2 & 47.7 & 30.6 & 142 \\
\hline Big & 0 & 0 & 0 & 0 & 0.176 & 58.7 & 18.5 & 3.78 & 2.67 & 0.445 & 0.001 & 0 & 7.02 \\
\hline
\end{tabular}

and into Minto Inlet, and the Big River and the similarly sized Bernard River on Banks Island. River flows reflect the differences in precipitation described in the section on climate. Rivers flowing out of the British and Mackenzie Mountains and across the Yukon Coastal Plain or into the Mackenzie Delta have flows per area ranging from 6.49 to $9.76 \mathrm{l} / \mathrm{s} / \mathrm{km}^{2}$. By comparison, flows are 2.53 to $3.64 \mathrm{l} / \mathrm{s} /$ $\mathrm{km}^{2}$ for Mackenzie Delta and Anderson Plain ecoregion streams and only $1.92 \mathrm{l} / \mathrm{s} / \mathrm{km}^{2}$ for the only metered stream on Banks and Victoria Islands. West of the Mackenzie, stream flows are actually greater than the precipitation rates in the area would predict (Table 1), but it must be remembered that the weather stations are on the coast, not high in the mountains, where precipitation is estimated to be much higher. In addition, the standard rain gauges and snow rulers used to measure precipitation are prone to under-measurement in windy areas such as tundra (Thompson, 1993).

The rivers flowing into the Canadian Beaufort Sea show extreme seasonal fluctuations in flow. Major flow periods generally coincide with the spring melt (Table 3 ). As a consequence of the low storage capacity of the underlying permafrost and tundra in the basins, rainstorms can cause pulses of high water during the open water season. Spring flows start in mid to late May in the mainland rivers (later on Banks and Victoria Islands) and peak in June. The Mackenzie River system consists of several major river systems and three major lakes, and its headwaters are far to the south of the Beaufort Sea. The result is that while peak flows are in June, the discharge remains relatively high throughout the year when compared to that of the smaller Arctic rivers, whose flow is almost exclusively due to the spring melt. Of the rivers with stream gauges, only the Arctic Red, the Peel, and the Anderson continue to flow during the winter, and at volumes much smaller in relation to river size than those of the Mackenzie.

The Mackenzie River delivers more than 125 million tonnes of suspended sediment to the Mackenzie Delta annually. Other minor sources of sediment for the Canadian Beaufort Sea are the rivers along the Yukon coast (1.5 million tonnes) and erosion of coastal bluffs (5.6 million tonnes) (Hill et al., 1991). Coarse material settles near the mouth, but finer grained sediments may be carried much greater distances. Discharge and sediment supply from the Mackenzie are low during the winter months but rise rapidly in late April and May prior to breakup. The clay, silt, and fine sand are carried northward onto the continental shelf and then eastward. During the open water summer months, a surface plume of brackish water with relatively high concentrations of suspended sediment extends over much of the shelf east of the Delta. (Hill et al., 1991). Sedimentation rates off the Mackenzie Delta are $4-5 \mathrm{~m}$ per 1000 years, while areas to the east and in other locations more exposed to bottom currents or farther from the Mackenzie receive only $0.25 \mathrm{~m}$ per 1000 years (Pelletier, 1984).

The water-mass circulation of the Canadian Beaufort Sea and Mackenzie River estuary has been the focus of many studies (e.g., Aagaard and Carmack, 1989; Macdonald et al., 1989, 1995; Carmack and Macdonald, 2002). Tides are small, less than $0.5 \mathrm{~m}$ at Tuktoyaktuk, but summer storm surges can reach over $2 \mathrm{~m}$ (Percy et al., 1985). Water masses in the surface layer are primarily freshwater from the Mackenzie River and icemelt water (Macdonald et al., 1989). There is generally a westward flow along the coast during the summer as a result of the dominant easterly winds. Offshore of about the $50 \mathrm{~m}$ depth contour, an undercurrent eastward flow extends to the base of the continental slope throughout the year (Aagaard, 1984). Each winter, the freshwater becomes impounded under the landfast ice, which extends from shore to approximately the $20 \mathrm{~m}$ depth contour. At the seaward edge of the landfast ice, a deep zone of ice rubble forms a barrier to the Mackenzie River water (Macdonald et al., 1995; Carmack and Macdonald, 2002). The pack ice moves westward in the Beaufort Sea Gyre. In winter, its nearshore edge lies approximately over the $500 \mathrm{~m}$ depth contour, near the edge of the continental shelf (AMAP, 1998). The dynamic transition zone between the pack ice and the landfast ice is an important part of the marine ecosystem. Most years, there is recurrent open water in the Cape Bathurst area. By the end of May, an extensive lead system exists from the northwest coast of Banks Island south to the entrance of Amundsen Gulf and west to the seaward edge of the landfast ice offshore of the Tuktoyaktuk Peninsula (Stirling and Cleator, 1981). See Carmack and Macdonald (2002), Dickson and Gilchrist (2002), Harwood and Smith (2002), Stirling (2002), and Usher (2002) for discussions on the importance of seasonal changes in ice cover both to sea birds and mammals and to resource harvesters. 


\section{THE PEOPLES OF THE CANADIAN BEAUFORT SEA REGION}

The dividing line between "prehistory" and "history" is often arbitrary; in the context of this paper, it coincides roughly with the period of European contact. For a broad, yet detailed description of the prehistoric period see McGhee (1996). His cogent treatment of the subject synthesizes results from his own extensive research and that of other recent authors. The following discussion of the prehistory of the Beaufort Sea region is based primarily on McGhee's (1996) synthesis.

We use the term "Eskimo" with no pejorative connotation (it is the transliteration of a Cree Indian word meaning "eaters of raw meat"), but rather following the anthropological convention of using it to refer to all the peoples who speak Inuit languages of the Eskimo-Aleut family. It does not include the Aleuts or the Chukchi peoples, who are considered to have the same Arctic Mongoloid ancestry but diverged culturally and linguistically, likely while still in Asia. The Siberian and Alaskan Inuit still refer to themselves as Eskimos, but nowadays the term "Inuit" (people) is more commonly used by, and for, the populations of Arctic Canada and Greenland.

It is widely held that the earliest inhabitants of North America were the Amerindian ancestors, who traversed the Bering land bridge long before the Eskimo ancestors and subsequently spread to the south and to the east. Their northern boundary is generally considered to be the tree line. The earliest known habitation of these people in North America may be at a site on the Old Crow River in an unglaciated part of what is now the Yukon Territory. At this site, animal remains, which may include some that have been anthropogenically modified, have been radiocarbon-dated to 27000 B.P. or earlier. Between 8000 and 4000 years ago, the tree line was farther north, and Amerindian caribou hunters occupied the Low Arctic seasonally.

The Palaeo-Eskimo occupation of the Arctic is believed to have occurred in waves. The first such wave appears to have been a very rapid expansion across all the maritime Arctic regions, and later into the Barren Grounds. The first occupation of these areas occurred ca. 4500-4000 years ago, and a broad-based economy of land, sea, and river resources had been established by 4000 B.P.

The Dorset people (2800-1000 B.P.), who are probably the Tuniit of Inuit legend, appear to have evolved in situ from the pre-Dorset people: i.e., there was no replacement by new people. This accelerated cultural change occurred, perhaps somewhat surprisingly, during a cooling trend, when there was a decrease in both geographic range and population size. The Dorset people exhibited a widespread coastal expansion as far south as Newfoundland and a more maritime-oriented economy, which included walrus and beluga. Their rather sudden disappearance around 1100-1000 B.P. coincided with the onset of a warming trend.
The second population wave was the Thule expansion, which resulted in a uniform Eskimo population from the Bering Strait to Greenland. Thule culture is considered to be more specialized and uniform than that of the historic period. The Thule people developed around 1500-1000 B.P. from the Birnirk culture of North Alaska. The Birnirk were coastal sea mammal hunters but, in contrast to their Thule descendants, they did not hunt the bowhead whale.

The Thule migration route followed the coast from Point Barrow, through Amundsen Gulf, up into the Arctic Islands, and ultimately to West Greenland. Since the Thule were bowhead hunters, they may have followed the bowhead eastward (Dyke et al., 1996).

Within Arctic Canada, the Thule winter villages were smaller than those in Alaska. This likely reflects a change in whaling patterns: these hunters chased whales offshore in umiaks and kayaks rather than taking them in narrow shore leads. Their summer groups are estimated to have numbered $10-50$ people.

In a later expansion of uncertain time frame, the Thule moved into more ecologically diverse areas, and increasing regional differences probably resulted from isolation or local adaptation. This left small "tribes," which are loosely related to the "tribes" of the historic period. Isolation was certainly not total, as there is evidence of trade, especially in iron, including meteoritic iron items from old Norse settlements on the Greenland coast as well as iron from Siberia. During this later phase, bowhead whaling remained important, but the location of more villages outside the bowhead feeding range indicates that emphasis was shifting to other resource species.

About 800 years ago, the Thule economy began to experience a restriction on whaling activities. This was the onset of another cooling trend, which became the Little Ice Age (350-150 B.P.) This change could have led to the emphasis on hunting terrestrial mammals in the summer and seals in the winter. The Thule abandoned the High Arctic at about this time (actual date unknown), and the Low Arctic groups underwent local adaptations that gave rise to some ten historic groups recognized today. One of these historic groups of Thule ancestry is the Mackenzie Eskimos, and these people are the predecessors of the Inuvialuit.

Before the 19th-century contact with Europeans, the Mackenzie Eskimos occupied the western Arctic coast from Barter Island to Cape Bathurst. Their population at this time has been estimated at 2000-4000: a larger population than that estimated for all other Canadian Eskimos put together. This may have given rise to the claim inside its old Anglican Church that Aklavik was the ancestral home of $80 \%$ of Canada's Inuit.

In the late 19th and early 20th centuries, Europeans introduced a series of epidemics to which the Mackenzie peoples had no natural immunity. By 1910, according to McGhee (1974), disease had reduced the populations to a few score. These few were admixed with the huge influx of Alaskan Eskimos who accompanied the European whalers 
and traders. These factors accelerated the disintegration of the Mackenzie Eskimo culture, which was complete by 1941, when it is thought the last survivor died (Billy Day, pers. comm. 2000).

This untimely extinction has left little information on the history and culture of the Mackenzie Eskimo. The oral traditions have been compiled in Inuvialuit Pitqusiit (Department of Education, 1991), and McGhee (1974) consolidated the archaeological information and that contained in the random writings of explorers, traders, and missionaries. Five groups are identified. Intermarriage between the various groups occurred, but its extent is not really known. The names given are those by which the people referred to themselves: they are taken from the central villages of each group.

Kigirktarugmiut. This group was centred on Herschel Island, near the Alaska-Yukon border. They traded with Alaskan Eskimos and the Vuntut Gwich'in, and were the first to feel the impact of the whalers.

Kupugmiut. This group was centred at Kupuk on the eastern edge of Richards Island at the mouth of the Mackenzie River's East Channel and opposite Kittigazuit.

Kittegaryumiut. This group takes its name from the location nowadays referred to as Kittigazuit. With a summer population of around 1000, it was the largest centre in the region. Its hunting area extended to modern-day Tuktoyaktuk, Husky Lakes, Arctic Red River, and perhaps farther southwards.

Nuvorugmiut. This group was centred on Nuvurak (Atkinson Point), and its area was primarily what is now known as the Tuktoyaktuk Peninsula.

Avvagmiut. This group occupied the area to the east of Liverpool Bay, including the Anderson River area. The Avvagmiut hunted bowhead whales from Cape Bathurst, and it has been suggested that they may represent two distinct groups (Usher, 1971).

The mid to late 19th century saw the arrival of European missionaries, fur-traders from the South, and whalers and Inupiat from the West. Such contact profoundly influenced the cultural and genetic makeup of the present-day Beaufort region. Intermarriage also occurred with the neighbouring Dene groups (present day Gwich'in). Law enforcement (RCMP) and educational matters were also beginning to be addressed within the region. Initially, education was pursued along religious sectarian lines epitomized by the residential schooling system, the structural elements of which have only recently dissolved.

Following World War II, Canada and other countries entered the Cold War era. Arctic sovereignty was taken more seriously, as was Canada's role in maintaining global security. The Distant Early Warning (DEW line) chain of sites was constructed with the help of the United States. This massive construction effort in remote Arctic areas gave many local residents their first exposure to a wageearning economy and the opportunity to diversify their skills. The DEW line has now evolved into the North Warning System (NWS).
The period between the DEW line and the NWS saw the advent of exploration for oil and gas in Canada's Arctic frontier. Initially, scant attention was paid to the fact that people actually lived in this frontier, let alone to the rights that they might have to their own backyard. The late 1960s and early 1970s brought this issue clearly into focus. In 1968, oil was discovered at Prudhoe Bay, Alaska, and a Mackenzie Valley pipeline was proposed. In the following year, Canada established the Task Force on Northern Oil Development. In 1970, Esso discovered oil at Atkinson Point, and the Committee for Original Peoples Entitlement (COPE) was formed. This group paved the way for the settlement of comprehensive land claims. Its proposed court action with respect to seismic exploration on Banks Island led to the promulgation of the federal Territorial Land Use Regulations.

The Canadian Arctic Gas pipeline was proposed in 1971, and in 1973 the Calder Case led to the establishment of a federal Comprehensive Land Claims policy in August of that year, and the Inuit Land Use and Occupancy study was initiated. It was completed in 1975 , by which time Dome Petroleum had received approval-in-principle for offshore drilling, Canadian Arctic Gas Systems Ltd. had submitted a Mackenzie Valley Pipeline application, and Justice Berger had been appointed to conduct an inquiry into this proposed development. The Berger hearings, begun in 1975 and completed a year later, concluded that a Mackenzie Valley gas pipeline could be constructed to meet extant environmental standards but should be deferred for 10 years to avoid disrupting the socioeconomic fabric of the Mackenzie communities. The federal government endorsed this recommendation, but exploration for oil and gas on offshore Crown lands in the Beaufort Sea was allowed to continue. By the early 1980 s, economic factors had caused the slowdown and eventual cessation of oil and gas exploration activities in the Western Canadian Arctic. This hiatus continued until very recently, but there is now renewed interest in Delta gas and a Mackenzie Valley pipeline, and most of the offshore leases remain active.

An unresolved international issue in the Beaufort Sea is the maritime boundary between Canada and the United States. In 1977, spurred by large-scale hydrocarbon exploration following the 1968 Prudhoe Bay discoveries, Canada and the United States began negotiations to resolve their boundary dispute. Canada held that the offshore boundary was simply an extension of the meridian at $141^{\circ} \mathrm{W}$, the Alaska-Yukon boundary. The United States countered that the maritime boundary should follow a line equidistant from the two countries, which would fall to the northeast of the 141st meridian. Bilateral talks took place in three phases between 1977 and 1978, but the two sides were unable to arrive at a mutually satisfactory arrangement. No substantive attempts to resolve the Beaufort Sea boundary have taken place since that time (Kirkey, 1995). To date, no hydrocarbon exploration leases have been sought or granted within the disputed area. 


\section{DESCRIPTION OF PRESENT COMMUNITIES IN THE REGION}

The region has eight permanent communities, Inuvik, Aklavik, Fort McPherson, Tsiigehtchic, Tutkoyaktuk, Paulatuk, Sachs Harbour, and Holman, as well as a large number of traditional campsites and cabins used for subsistence purposes at various times throughout the year. Although the recent gas exploration boom has begun to have a positive effect on the region, the provision of municipal and government services remains a major economic factor for all its communities. Few entrepreneurial opportunities exist in the smaller communities, and the limited commercial use of renewable resources provides much-needed revenue where other sources are scarce. Similarly, subsistence harvesting is more significant in communities where there are fewer wage-earning opportunities. Even so, however, the number of full-time trappers is much smaller than it was a few years ago. The eight permanent communities are described briefly below.

\section{Inuvik}

Located on the east branch of the Mackenzie River, Inuvik is the largest permanent community in the region. At present the town has some 3200 residents, which include an Inuvialuit population of 2000 and a Gwich'in population of 300 . Inuvik was built as the regional centre for government, a function that it retains to the present day.

This concept was born in the late 1940s, when the Canadian government decided to establish in the Mackenzie Delta area a permanent communications centre that would also serve the Western Arctic with respect to education, administration, and transportation. In addition, this centre was intended to be the relocation site for the residents of Aklavik, a community located on a point bar on the West Channel of the Mackenzie River, where it was subject to flooding and the longer-term destructive deltaic process of channel meandering.

On the site originally dubbed the "East Three" by survey team engineers, materials were stockpiled in 1954, and construction began the following year. The site was provided with an airfield capable of handling airliner traffic and a dock for large vessel traffic. It received its present name in 1958 , and the town quickly fulfilled the original concept with the provision of residential schools, a large hospital, an RCMP detachment, and other government buildings and housing. The military set up a "listening post" at the end of Navy Road and a sizable Canadian Forces establishment in the town. The latter became the Aurora Campus of Arctic College following the withdrawal of the Armed Forces in 1986. The federal Department of Indian Affairs and Northern Development established the Inuvik Research Laboratory to promote and facilitate Arctic research. The laboratory building, which also housed a cosmic ray counter, is now the Aurora Research Institute run by the Northwest Territories government. The town pioneered innovative ways of dealing with construction on permafrost, such as an aboveground water/sewage system (with insulated conduits called "utilidors") and the use of pilings as structural foundations.

Notwithstanding more recent developments, the subsistence lifestyle is still very much in evidence in Inuvik, as it is in all the region's communities.

\section{Aklavik}

This community comprises some 700 people, primarily Inuvialuit (50\%) and Gwich'in (40\%). It was the regional centre before the establishment of Inuvik and, despite the government's intention that Inuvik would become the "new Aklavik," it has remained a viable communityhence the hamlet motto: "Never say die." Aklavik was also the epicentre of the notorious "Mad Trapper" incident, which involved W.O.P. May and the first use of an airplane in the pursuit of a criminal. Aklavik was also the birthplace of Nellie Cournoyea, Canada's first elected female government leader of aboriginal descent.

\section{Fort McPherson}

This community of approximately 1000 residents, primarily Gwich'in, is located on the east bank of the Peel River near its junction with the Mackenzie River. Established as a Hudson's Bay Company fur trading post in 1840 , it was named after one of that company's chief traders. Fort McPherson became a link with the Yukon and was the terminus of one of the most famous RCMP Annual Patrols, which originated in Dawson City. One of these patrols, led by Inspector Fitzgerald in 1911, ended in tragedy a few miles from Fort McPherson. The "Lost Patrol" has become part of the local folklore.

The community boasts numerous notable historical "firsts": Father Grollier, the first missionary in the region (1860); John Firth, the first government law officer (1894); Reverend Edward Sittichinli, the first ordained Native minister (1903); Chief John Tetlichi, the first Dene member of the Territorial Council (1967); Wally Firth, the first northern Native MP (1972); and Richard Nerysoo, Canada's first elected government leader of aboriginal descent, and the former president of the Gwich'in Tribal Council.

\section{Tsiigehtchic}

Formerly known as Arctic Red River, this is the smallest Gwich'in community in the region, with a population approaching 200. It is located near the confluence of the Arctic Red and Mackenzie Rivers and is the site of a ferry crossing for the Dempster Highway during the ice-free season. (The other ferry crossing is at the Peel River near Fort McPherson.) This highway has greatly improved transportation and has facilitated contact between Tsiigehtchic, Fort McPherson, the Delta communities, and 
the Yukon. It also brings increasing numbers of tourists to the region.

\section{Tuktoyaktuk}

This primarily Inuvialuit community, with a population of almost 1000, is the only deepwater port in the region. This feature made it a focus of exploration activity in the 1970s, when the oil and gas industry expanded into the offshore areas of the Canadian Beaufort Sea. This use of the harbour, and the establishment of large personnel and equipment bases around it, almost doubled the size of the population during peak periods. Several of these structures remain, and more are being put to use as the level of hydrocarbon exploration in the area increases. A local Inuvialuit business, E. Gruben's Transport Ltd., has grown considerably over the past two decades and remains a thriving and highly successful company.

Although Tuktoyaktuk is a coastal community, the subsistence activities of its residents extend inland and include part of the Mackenzie Delta.

\section{Paulatuk}

Originally a small Inuvialuit settlement at the mouth of the Hornaday River engaged primarily in subsistence activities, this community now has a population approaching 300 and is the gateway to the newest National Park in the region: Tuktut Nogait. Paulatuk has also recently become the focus of the highest level of mineral exploration of any community in the region to date.

\section{Sachs Harbour}

This is the smallest Inuvialuit community, with a population of approximately 100. In the early 1900s, Inuvialuit families from the mainland and from Victoria Island would go to Banks Island to trap arctic fox (Alopex lagopus). Permanent occupation began in 1929, and the trade in fox pelts was so lucrative that it led to the "Schooner Era," when some of the natural wealth was used to acquire large vessels to transport furs to centres such as Aklavik. This was somewhat ironic since it coincided with the Great Depression being experienced in the 1930s by the rest of the North American continent.

Continuous occupation was acknowledged by the establishment of a RCMP post in 1953. An Upper Air Station was built in 1954, and Fred Carpenter opened the first store in 1958. Today Sachs Harbour is the headquarters of Aulavik National Park, but the meteorological station has been closed down. The anti-trapping movement and the decline of the fur industry have seriously affected this community. At present, limited tourist activity, sports hunts, and sporadic commercial harvests of the burgeoning muskox population provide the only nongovernmental employment.

\section{Holman}

This Inuvialuit community on the west coast of Victoria Island numbers over 400 people. It is home to the internationally famous Holman Annual Print Collection, and is considered by many to be one of the most traditional Inuit communities. Holman has a somewhat eastern Arctic character, which is not coincidental, since many residents have family ties with neighbouring Nunavut communities. Seals always featured prominently in the Holman economy until the anti-sealing movement bought about a major downturn in this market.

\section{LAND SETTLEMENT AGREEMENTS IN THE CANADIAN BEAUFORT SEA REGION}

The Inuvialuit Final Agreement (IFA), signed on 5 June 1984, was the first comprehensive land-claim settlement for a region wholly within Arctic Canada. The second such settlement was the Gwich'in Final Agreement, signed on 22 April 1992. Both agreements have established processes for wildlife management in which the government and the aboriginal people jointly manage renewable resources. The "co-management" structures of the Inuvialuit Settlement Region (ISR) and the Gwich'in Settlement Area (GSA) have the same basic goals and incorporate the principle of conservation, but the structures by which these goals are achieved are somewhat different. This is because after the first comprehensive claim (Inuvialuit), all subsequent claims were settled using a different model.

The IFA has created two parallel series of structures. The first is the six Community Corporations that make up the Inuvialuit Regional Corporation (IRC). The IRC has revenue-generating subsidiary corporations and businesses, and is funded via these private sources. The second is the six Hunters and Trappers Committees, which make up the Inuvialuit Game Council (IGC). The Game Council, as well as the co-management bodies, are supported entirely by government implementation funding.

The Gwich' in have similar community-level organizations, but a single Tribal Council represents their collective interest. The Inuvialuit system, in contrast, has one organization (the IGC) representing the collective interest in all matters related to wildlife, and another (the IRC) representing the collective interest in all other matters, e.g., enrolment of beneficiaries to the claim, land administration, social programs, and economic measures.

The co-management bodies are also somewhat different in the two claims, but both maintain the principle of equal beneficiary/government membership. Furthermore, all Gwich'in co-management bodies are institutions of public government, as opposed to the IFA structures, which are advisory in nature. Although they have different descriptors, in practice their operations are not very dissimilar, since the appropriate government minister has the final say on all decisions. 
The Gwich'in Renewable Resources Board, which comanages all wildlife within the GSA, is the counterpart of three co-management bodies for the ISR. This is because fish and marine mammals in the ISR are co-managed by a separate body (the Fisheries Joint Management Committee). Secondly, since the ISR falls into two territorial jurisdictions, terrestrial and avian wildlife is managed by two bodies (one Wildlife Management Advisory Council for the Yukon North Slope, and another for that part of the ISR that falls within the Northwest Territories).

The Gwich'in Environment Review Board fulfils both the screening and review functions for developments affecting the GSA, whereas for the ISR these functions are split between two co-management bodies (the Environmental Impact Screening Committee and the Environmental Impact Review Board).

For a more detailed treatment of these co-management processes within the ISR, see Green and Binder (1995) and Bailey et al. (1995).

\section{ACKNOWLEDGEMENTS}

The contributions of Marta Wojnarowska of the Department of Fisheries and Oceans (DFO), who calculated watershed areas, and Mike Muller of the Joint Secretariat - Inuvialuit Renewable Resources Committees, who drafted the illustrations, are gratefully acknowledged. We would like to thank Billy Day, who reviewed an earlier version of the manuscript, as well as individuals from the DFO, the Geological Survey of Canada, the Joint Secretariat, Environment Canada, and Parks Canada who provided background material and identified sources of information. Errors or omissions are those of the authors, not the people who so graciously provided assistance.

\section{REFERENCES}

AAGAARD, K. 1984.The Beaufort undercurrent. In: Barnes, P.W., Schell, D.M., and Reimnitz, E., eds. The Alaskan Beaufort Sea: Ecosystems and environments. Orlando, Florida: Academic Press. 47-71.

AAGAARD, K., and CARMACK, E.C. 1989. The role of sea ice and other freshwater in the Arctic circulation. Journal of Geophysical Research 94:485-498.

AMAP. 1998. AMAP assessment report: Arctic pollution issues. Oslo: Arctic Monitoring and Assessment Programme. xii + 859 p.

ATMOSPHERIC ENVIRONMENT SERVICE. 1990. Canadian climate normals 1961-1990, Yukon and Northwest Territories. Canadian Climate Program, Environment Canada. 36 p.

. 2001. HYDAT: Surface water and sediment data (CDROM). Downsview, Ontario: Atmospheric Environment Service.

BAILEY, J.L., SNOW, N.B., CARPENTER, A., and CARPENTER, L. 1995. Cooperative wildlife management under the Western Arctic Inuvialuit Land Claim. In: Bissonette, J.A., and Krausman, K.R., eds. Integrating people and wildlife for a sustainable future. Proceedings of the First International Wildlife
Management Congress, 19-25 September, San Jose, Costa Rica. Bethesda, Maryland: The Wildlife Society. 11-15.

BERRY, M.O., DUTCHAK, P.M., LALANDE, M.E., McCULLOCH, J.A.W., and SAVDIE, I. 1975. A study of weather waves and icing in the Beaufort Sea. Beaufort Sea Project. Technical Report No. 21. Sidney, British Columbia: Department of Fisheries and Oceans, Institute of Ocean Sciences.

BLASCO, S.M., FORTIN, G., HILL, P.R., O'CONNOR, M.J., and BRIGHAM-GRETTE, J. 1990. The late Neogene and Quaternary stratigraphy of the Canadian Beaufort continental shelf. In: Grantz, A., Johnson, L., and Sweeney, J.F., eds. The Arctic Ocean region. The Geology of North America, Vol. L. Boulder, Colorado: Geological Society of North America.

BRUNSKILL, G.J. 1986. Environmental features of the Mackenzie system. In: Davies, B.R., and Walker, K.F., eds. The ecology of large river systems. Dordrecht, The Netherlands: Dr. W. Junk Publishers. 435-472.

BURNS, B.M. 1973. The climate of the Mackenzie Valley-Beaufort Sea. Vol. 1. Climate Studies No. 24. Toronto: Atmospheric Environment Service. 227 p.

- 1974. The climate of the Mackenzie Valley-Beaufort Sea.

Vol. 2. Climate Studies No. 24. Toronto: Atmospheric Environment Service. 239 p.

CARMACK, E.C., and MACDONALD, R.W. 2002. Oceanography of the Canadian Shelf of the Beaufort Sea: A setting for marine life. Arctic 55(Supp. 1):29-45.

COHEN, S.J. 1997. What if and so what in Northwest Canada: Could climate change make a difference to the future of the Mackenzie Basin? Arctic 50(4):293-307.

DEPARTMENT OF EDUCATION. 1991. Inuvialuit Pitqusiit: The culture of the Inuvialuit. Yellowknife: Government of the Northwest Territories, Department of Education. 87 p.

DICKSON, L., and GILCHRIST, H.G. 2002. Status of marine birds of the southeastern Beaufort Sea. Arctic 55(Supp. 1):46-58.

DOMEPETROLEUMLTD, ESSORESOURCES CANADALTD, and GULFCANADA RESOURCES INC. 1982a. Environmental impact statement for hydrocarbon development in the Beaufort Sea - Mackenzie Delta region Vol. 3A. Beaufort Sea-Delta setting. $1.1-4.127 \mathrm{p}$.

DOWNIE, B.K. 1995. Cultural and natural background research for the proposed Tuktut Nogait National Park. Unpubl. report available from Parks Canada, Box 1840, Inuvik, Northwest Territories X0E 0T0. 103 p.

DYKE, A.S., and PREST, V.K. 1987a. Paleogeography of northern North America, 18 000-5 000 years ago. Geological Survey of Canada. Map 1703A.

1987b. Late Wisconsin and Holocene retreat of the Laurentide Ice Sheet. Geological Survey of Canada. Map 1702A.

DYKE, A.S., HOOPER, J., and SAVELLE, J.M. 1996. A history of sea ice in the Canadian Arctic Archipelago based on postglacial remains of the bowhead whale (Balaena mysticetus). Arctic 49(3):235-255.

ENVIRONMENT CANADA. 1998. Climate trends and variations bulletin for Canada. http://www.msc-smc.ec.gc.ca/ccrm/bulletin/ page2.htm (Date accessed: 13 December 2001).

. 2001. Narrative descriptions of terrestrial ecozones and ecoregions of Canada. http://www.ec.gc.ca/soer-ree/English/ 
Framework/nardesc/default.cfm (Date accessed: 13 December 2001).

FYLES, J.G. 1990. Beaufort Formation (Late Tertiary) as seen from Prince Patrick Island, Arctic Canada. Arctic 43(4): 393-403.

GREEN, N., and BINDER, B. 1995. Environmental impact under the Western Arctic (Inuvialuit) Land Claim. In: Bissonette, J.A., and Krausman, K.R., eds. Integrating people and wildlife for a sustainable future. Proceedings of the First International Wildlife Management Congress, 19-25 September, San Jose, Costa Rica. Bethesda, Maryland: The Wildlife Society. 343-345.

HARWOOD, L.A., and SMITH, T.G. 2002. Whales of the Inuvialuit Settlement region in Canada's Western Arctic: An overview and outlook. Arctic 55(Supp. 1):77-93.

HILL, P.R., BLASCO, S.M., HARPER, J.R., and FISSEL, D.B. 1991. Sedimentation on the Canadian Beaufort Shelf. Continental Shelf Research 11(8-10):821-842.

HILLS, L.V., KLOVAN, J.E., and SWEET, A.R. 1974. Juglans eocinera n. sp., Beaufort Formation (Tertiary), southwestern Banks Island, Arctic Canada. Canadian Journal of Botany 52(1):65-90.

JUDGE, A.S., PELLETIER, B.R., and NORQUAY, I. 1987. Permafrost base and distribution of gas hydrates. In: Pelletier, B.R., ed. Marine science atlas of the Beaufort Sea, geology and geophysics. Geological Survey of Canada. Miscellaneous Report 40:39.

KARASIUK, D.J. 1993. Ecological overview of Northern Yukon National Park. In: Northern Yukon National Park resource description and analysis. RM Report 93-01/INP, Chapter 1. Winnipeg: Natural Resource Conservation Section, Canadian Parks Service, Prairie and Northern Region. 32 p.

KARASIUK, D.J., BIRCH, G.J., SLANEY, T.L., and McPHAIL, J.D. 1993. Aquatic resources of northern Yukon National Park. In: Northern Yukon National Park resource description and analysis. RM Report 93-01/INP, Chapter 7. Winnipeg: Natural Resource Conservation Section, Canadian Parks Service, Prairie and Northern Region. 221 p.

KENNETT, J.P. 1982. Marine geology. Englewood Cliffs, New Jersey: Prentice-Hall, Inc. 813 p.

KIRKEY, C. 1995. Delineating maritime boundaries: The 197778 Canada-U.S. Beaufort Sea continental shelf delimitation boundary negotiations. Canadian Review of American Studies 25(2):49-67.

LEITH, R.M. 1993. Hydrology of Northern Yukon National Park. In: Northern Yukon National Park resource description and analysis. RM Report 93-01/INP, Chapter 6. Winnipeg: Natural Resource Conservation Section, Canadian Parks Service, Prairie and Northern Region. 60 p.

MACDONALD, R.W., WONG, C.S., and ERICKSON, P. 1987. The distribution of nutrients in the southeastern Beaufort Sea: Implications for water circulation and primary production. Journal of Geophysical Research 92:2939-2952.

MACDONALD, R.W., CARMACK, E.C., McLAUGHLIN, F.A., ISEKI, K., MACDONALD, D.M., and O'BRIEN, M.C. 1989. Composition and modification of water masses in the Mackenzie shelf estuary. Journal of Geophysical Research 94:18057-18070.
MACDONALD, R.W., PATON, D.W., CARMACK, E.C., and OMSTEDT, A. 1995. The freshwater budget and under-ice spreading of Mackenzie River water in the Canadian Beaufort Sea based on salinity and 180/160 measurement in water and ice. Journal of Geophysical Research 100:895-919.

MACKENZIE RIVER BASIN COMMITTEE. 1981. Mackenzie River Basin Study Report. A report under the 1978-81 FederalProvincial Study Agreement respecting the water and related resources of the Mackenzie River Basin. 231 p.

MARSHALL, I.B., and SCHUT, P.H. 1999. A national ecological framework for Canada. Ecosystems Science Directorate, Environment Canada, and Research Branch, Agriculture and Agri-Food Canada, Ottawa/Hull.http://sis.agr.gc.ca/cansis/nsdb/ ecostrat/intro.html

MAXWELL, J.B. 1981. Climatic regions of the Canadian Arctic Islands. Arctic 34(3):225-240.

McDONALD, B.C., and LEWIS, C.P. 1973. Geomorphic and sedimentologic processes of rivers and coast, Yukon coastal plain. Environmental-Social Committee Northern Pipelines, Task Force on Northern Oil Development. Report No. 73-39. $249 \mathrm{p}$.

McGHEE, R. 1974. Beluga hunters: An archaeological reconstruction of the history and culture of the Mackenzie Delta Kittegaryumiut. Toronto: Canadian Museum of Civilization and University of Toronto Press. 124 p.

- 1996. Ancient people of the Arctic. Vancouver: Canadian Museum of Civilization and University of British Columbia Press. 244 p.

McMILLAN, N.J. 1986. Tertiary fossil forests in the Arctic. Episodes 9(3):169-170.

McNEIL, D.H. 1990. Tertiary marine events of the BeaufortMackenzie Basin and correlation of Oligocene to Pliocene marine outcrops in Arctic North America. Arctic 43(4): $301-313$.

NATIONAL CLIMATE DATA CENTER. 1998. National Oceanic and Atmospheric Administration. Climate of 1998 Annual Review.http://lwf.ncdc.noaa.gov/oa/climate/research/1998/ann/ ann98.html (Date accessed: 13 December 2001).

PELLETIER, B.R. 1984. Distribution and dispersal of bottom sediment types. In: Pelletier, B.R., ed. Marine science atlas of the Beaufort Sea sediments. Geological Survey of Canada. Miscellaneous Report 38:7.

, ed. 1987. Marine science atlas of the Beaufort Sea, geology and geophysics. Geological Survey of Canada. Miscellaneous Report 40. 39 p.

- 1999. Morphology of the Arctic Shelf adjacent to the Canadian Arctic Archipelago. Unpubl. Manuscript. Available from B.R. Pelletier, Terrain Sciences Division, Geological Survey of Canada, 601 Booth Street, Ottawa, Ontario K1A 0E9, Canada.

PERCY, R. 1975. Fishes of the outer Mackenzie Delta. Beaufort Sea Project, Technical Report 8. Available from the Department of Fisheries and Oceans, Freshwater Institute, 501 University Crescent, Winnipeg, Manitoba R3T 2N6. 114 p.

PERCY, R., SMILEY, B., and MULLEN, T. 1985. Fishes, invertebrates and marine plants: The Beaufort Sea and the search for oil. Sidney, British Columbia: Department of Fisheries and Oceans, Institute of Ocean Sciences. 166 p. 
PHILLIPS, D. 1990. Climates of Canada. Ottawa: Environment Canada.

SHAW, J., TAYLOR, R.B., SOLOMON, S., CHRISTIAN, H.A., and FORBES, D.L. 1998. Potential impacts of global sea-level rise on Canadian coasts. The Canadian Geographer 42(4): $365-379$.

STIRLING, I. 2002. Polar bears and seals in the eastern Beaufort Sea and Amundsen Gulf: A synthesis of population trends and ecological relationships over three decades. Arctic 55(Supp. 1): $59-76$.

STIRLING, I., and CLEATOR, H., eds. 1981. Polynyas in the Canadian Arctic. Canadian Wildlife Service Occasional Paper 45.

THOMPSON, B. 1993. Climate of Northern Yukon National Park. In: Northern Yukon National Park resource description and analysis. RM Report 93-01/INP, Chapter 2. Winnipeg: Natural Resource Conservation Section, Canadian Parks Service, Prairie and Northern Region. 48 p.

TRENHAILE, A.S. 1990. The geomorphology of Canada: An introduction. Toronto: Oxford University Press. 240 p.

USHER, P.J. 1971. The Bankslanders: Economy and ecology of a frontier trapping community. 3 Vols. Ottawa: Northern Science
Research Group, Department of Indian and Northern Affairs and Northern Development.

2002. Inuvialuit use of the Beaufort Sea and its resources, 1960-2000. Arctic 55(Supp. 1):18-28.

VINCENT, J.-S. 1989. Quaternary geology of the northern Canadian Interior Plains. In: Fulton, R.J., ed. Quaternary geology of Canada and Greenland. Geology of Canada, No. 1. Ottawa: Geological Survey of Canada. 100-173.

WELCH, D.M. 1993a. Geology of the Northern Yukon National Park. In: Northern Yukon National Park resource description and analysis. RM Report 93-01/IN, Chapter 3. Winnipeg: Natural Resource Conservation Section, Canadian Parks Service, Prairie and Northern Region. 59 p.

1993b. Geomorphology of the Northern Yukon National Park. In: Northern Yukon National Park resource description and analysis. RM Report 93-01/INP, Chapter 4. Winnipeg: Natural Resource Conservation Section, Canadian Parks Service, Prairie and Northern Region. $115 \mathrm{p}$.

ZOLTAI, S.C., SIROIS, J., and SCOTTER, G.W. 1992. A natural resource survey of the Melville Hills Region, Northwest Territories. Technical Report Series No. 135. Yellowknife: Western and Northern Region, Canadian Wildlife Service, Environment Canada. 121 p. 